Review Article

\title{
The Effectiveness of Drying on Residual Droplets, Microorganisms, and Biofilms in Gastrointestinal Endoscope Reprocessing: A Systematic Review
}

\author{
Hefeng Tian ${ }^{(},{ }^{1}$ Jiao Sun, ${ }^{2}$ Shaoning Guo, ${ }^{1}$ Xuanrui Zhu, ${ }^{1}$ Han Feng, ${ }^{1}$ Yijin Zhuang, \\ and Xiu Wang ${ }^{1}$ \\ ${ }^{1}$ The First Hospital of Jilin University, Changchun, China \\ ${ }^{2}$ School of Nursing, Jilin University, No. 965 Xinjiang Street, Changchun, Jilin Province 130021, China \\ Correspondence should be addressed to Xiu Wang; wangxiu2009@jlu.edu.cn
}

Received 7 December 2020; Revised 21 March 2021; Accepted 23 March 2021; Published 8 April 2021

Academic Editor: Konstantinos Triantafyllou

Copyright (C) 2021 Hefeng Tian et al. This is an open access article distributed under the Creative Commons Attribution License, which permits unrestricted use, distribution, and reproduction in any medium, provided the original work is properly cited.

\begin{abstract}
Background. Despite endoscope reprocessing, residual droplets remain in gastrointestinal endoscope working channels. Inadequate drying of gastrointestinal endoscope working channels may promote microbial reproduction and biofilm formation, increasing the risk of infection in patients. This review was designed to provide the current status of gastrointestinal endoscope drying, emphasize the importance of gastrointestinal endoscope drying, and evaluate the effectiveness of different drying methods of gastrointestinal endoscope in reducing residual droplets and microbial growth risk. Methods. A systematic review was conducted according to the Preferred Reporting Items for Systematic Reviews and Meta-Analyses (PRISMA) reporting checklist. The PubMed, Web of Science, Medline, EMBASE, EBSCO, CNKI, CQVIP, and Wanfang Data databases were searched from 2010 to 2020 to identify eligible articles focused on methods of gastrointestinal endoscope drying and the status of endoscope drying. The following key points were analyzed: type of intervention, amount of residual droplets, major microbial types, and effectiveness of biofilm intervention. JBI quality assessment tool was used to determine bias risk for inclusion in the article. Results. This review included twelve articles. Two of the articles reported lack of drying of gastrointestinal endoscopes while the other ten reported residual droplets, microbial growth, and biofilm formation after different methods of drying. Four articles reported 0 to 4.55 residual droplets; four articles reported that the main microbial types were cocci and bacilli, most commonly Staphylococcus, Escherichia coli, Bacillus maltophilia, and Pseudomonas aeruginosa; and two reported that drying could effectively reduce biofilm regeneration. The type of intervention is as follows: automatic endoscopy reprocessor (AER), manual compressed air drying, and the Dri-Scope Aid for automatic drying and drying cabinet. Conclusions. While endoscope reprocessing may not always be effective, an automatic endoscope reprocessor plus the Dri-Scope Aid with automatic drying over 10 min or storage in a drying cabinet for $72 \mathrm{~h}$ may be preferred.
\end{abstract}

\section{Introduction}

Gastrointestinal endoscopy plays an important role in the prevention of digestive diseases [1]. Gastrointestinal endoscopy provides the possibility of early detection of cancer and a strong guarantee for accurate diagnosis of digestive diseases and is of great significance to improve the quality of life of human beings [2]. However, gastrointestinal endoscopes are invasive medical devices with fine structures, complex lumen, and special materials, which makes cleaning and dis- infection process difficult. Used endoscopes are used to diagnose and treat subsequent patients, which may lead to endoscope-related cross-infection [3,4].

The risk of microbial transmission is often underestimated due to the lack of systematic testing and laboratory testing coupled with limited awareness of bacterial transmission among healthcare workers [5]. In the past decades, hospitals around the world have reported endoscopic transmission outbreaks of multidrug resistance and water-borne organisms [6-8]. A striking problem was that some hospitals 
still had outbreaks despite strict adherence to endoscopic reprocessing guidelines [9]. Previous studies have shown that factors affecting microbial transmission include unreasonable design of instruments, endoscope damage, short cleaning time, low concentration of disinfectants, and inadequate drying [10]. To reduce the spread of endoscopic infection between patients. Endoscopy associations worldwide recommend reprocessing processes that generally include precleaning, leak detection, manual cleaning, rinsing, disinfection, terminal rinsing, drying, and storage $[1,11]$. It is worth noting that several recent trials have focused on improving the performance of high-level disinfection (HLD), but few trials have focused on enhancing and assessing the drying process [12-15]. In this paper, the effectiveness of residual droplet, microbe, and biofilm prevention via gastrointestinal endoscope drying is systematically reviewed to provide evidence to improve gastrointestinal endoscope reprocessing guidelines.

\section{Methods}

A systematic review was conducted according to the Preferred Reporting Items for Systematic Reviews and MetaAnalyses (PRISMA) reporting checklist [16] and Joanna Briggs Institute (JBI) literature quality assessment tools [17].

2.1. Search Strategy. This systematic review included all prevalence studies and quasirandomized controlled trials related to endoscope drying in the last decade identified from searches in eight databases (PubMed, Web of Science Core Collection, Medline, EMBASE, EBSCO, CNKI, CQVIP, and Wanfang Data) without language restrictions. See Supplementary File 1 for the detailed search strategy. Search terms were first input in each database retrieval box. Next, all the retrieved literature was imported into Endnote for unified management, and then, the titles and abstracts of the articles were independently screened by two reviewers (HF and YJ). If articles did not meet the inclusion criteria, they were excluded. Finally, the screening results of the two reviewers were compared. If there were differences of opinion or disagreement, a third person (XW) was consulted to resolve these issues.

Terms or keywords used in the database included "endoscop*," "gastroscop*," "gastrointesinal endoscop*," "enteroscop $*$," "duodenoscop $*$," "colonoscop $*$," "sigmoidoscop $*$," "proctoscop $*$," "rectoscop $*$," "endoscopic retrograde cholangiopancreatography," "ERCP," "dry*," and "desiccat*."

2.2. Eligibility Criteria. In order to make the evidence more adequate and complementary, prevalence studies and quasirandomized controlled trials were selected after screening. The eligibility criteria for these studies were as follows: (1) The type of article could be prospective, retrospective, observational, comparative, or randomized. (2) The contents of the prevalence studies should include the procedure for drying in endoscope reprocessing, and the quasirandomized controlled trials should specify the particular drying intervention methods. (3) The outcome measures for the effects of drying were residual droplets, microbial growth, and biofilm formation to assess the effectiveness of endoscope drying. If a search result only had an abstract without the full-text articles or the drying method was not described in detail, the article was excluded. The case reports of related infections due to insufficient endoscope drying were few and excluded from this systematic review.

2.3. Data Extraction and Quality Assessment. Data extraction tables were established in Microsoft Word documents. The two researchers ( $\mathrm{HF}$ and $\mathrm{YJ}$ ) independently reviewed all included articles in detail and extracted the relevant data, including the first author, publication date and type of article, type of endoscopy, sample size, measurement tools, intervention or survey modalities, and the results and conclusions of the article. Then, the data were analyzed and summarized, and inconsistent opinions were discussed with a third author (XW) to reach an agreement. Joanna Briggs Institute (JBI) literature quality assessment tools [17] were used to evaluate the prevalence studies and quasiexperimental controlled trials. Joanna Briggs Institute (JBI) literature quality assessment tools are composed of 18 items scored as "1 (yes)," "0 (not clear)," and "-1 (no)." The total quality is categorized as "low," "moderate," and "high" [17]. The main items included the intervention, control group, missing visits, data analysis method, sampling method, response rate, and sample size.

2.4. Synthesis and Analysis of the Data. Endnote was used to centrally manage the documents, and the data were recorded in Microsoft Word documents for synthesis and analysis. Considering that each article came from different countries, the endoscope reprocessing guidelines were inconsistent, the implementation of endoscope drying methods and outcome measures differed, and the heterogeneity was large, it was impossible to apply meta-analysis techniques to the data in this review. Therefore, this systematic review used descriptive methods to present the findings and results.

\section{Results}

3.1. Selection Process. A total of 2828 articles were retrieved from the 8 databases, and 1221 duplicate articles and 424 articles unrelated to the subject were identified using Endnote. The remaining 1183 articles were screened by their titles and abstracts. A total of 1120 articles were excluded according to the eligibility criteria, and the full-text versions of the remaining 63 articles were read. An article from Berlin in 2017 that described an endoscopic reprocessing drying procedure in detail was removed because it reviewed the horse medical endoscopy. Finally, this review included 12 articles. The specific screening flow chart is shown in Figure 1.

3.2. Characteristics of the Included Articles. Tables 1 and 2 summarize the characteristics of the included articles, with a total of 12 articles published within ten years. Five of them came from the United States; two came from China; two came from France; and the others were from the Netherlands $(n=1)$, Brazil $(n=1)$, and Ethiopia $(n=1)$. Three of the six prevalence studies reviewed were conducted through 


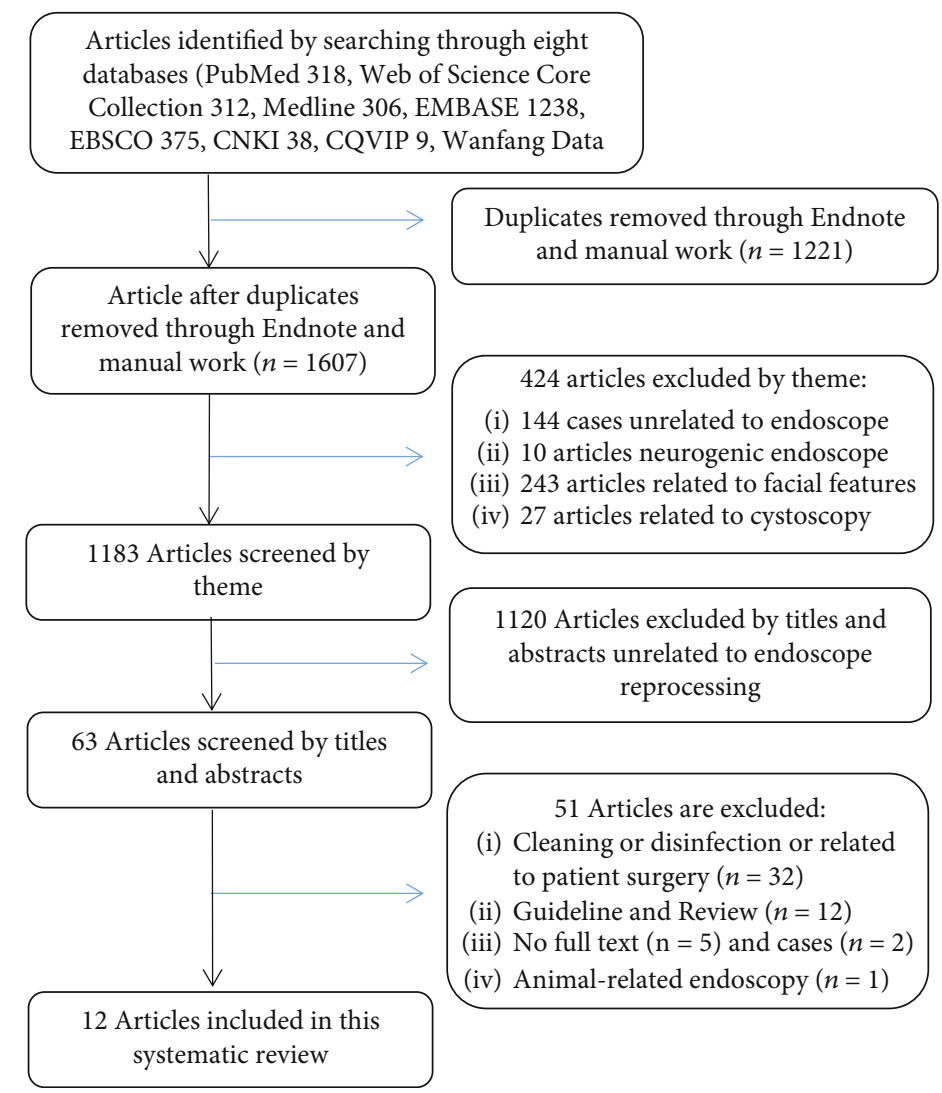

FIGURE 1: Flow diagram of articles included in the systematic review.

questionnaires, and the other three involved direct sampling of hospital endoscopes, with sample sizes from 45 to 295 . Table 3 summarizes the characteristics of the interventions. The six quasirandomized controlled trials were conducted using four drying methods. Two used sterile compressed air drying; two used specific endoscope storage cabinets to achieve medical air or efficient filtration of particulate air drying; one first used 75\% alcohol flushing for $3 \mathrm{~min}$ then compressed air to enhance the drying effect; and one used Dri-Scope Aid equipment for automatic drying, saving time and manpower. In these included articles, the types of endoscopes involved were gastroscopes, enteroscopes, duodenoscopes, etc. The JBI quality assessment tools were used to determine the risk of bias in the article. Although the twelve articles differed in terms of item bias, they had a low risk of bias overall.

3.3. Analysis of the Results. Of the twelve articles reviewed, two articles were related to lack of drying of gastrointestinal endoscopes. The remaining ten articles reported residual droplets $(n=4)$, microbial growth $(n=4)$, and biofilm formation $(n=2)$ after different methods of gastrointestinal endoscope drying. Tables 1 and 2 summarize the intervention and survey methods, results, and conclusions.

3.3.1. Lack of Dryness. Two articles investigated gastrointestinal endoscope dryness $[18,19]$. Barbosa et al. [18] evaluated a total of sixty endoscope reprocessing proce- dures in twenty institutions, and the results showed that there were some deficiencies in the reprocessing procedures; however, those in drying were the most serious. After endoscope cleaning and disinfection, twenty-four (40.0\%) endoscopes did not undergo external drying; eighteen $(30.0 \%)$ were improperly dried; and forty-five (75.0\%) endoscope internal working channels were not dried, while only six $(10.0 \%)$ were dried by compressed air. Another survey used a database of 2026 healthcare workers in the United States to distribute questionnaires to each person via e-mail. A total of 295 questionnaires were received from participants, including 71 physicians and 221 nurses who belonged to 249 different institutions [19]. The data showed that 119 institutions (47.8\%) dried by manual flushing of the endoscope channel or incorporating the endoscope into an automatic endoscope reprocessor for compressed air drying, and less than $50 \%$ of the investigated institutions used forced medical air drying [19].

3.3.2. Residual Droplets. Table 4 summarizes the effects of various drying methods on residual droplets in endoscopic instrument channels. Four articles reported the presence of residual droplets in endoscopes despite reprocessing [2023]. Thaker et al. [21] conducted a total of 97 examinations of 59 endoscopes in their hospital. Because no additional compressed air drying was performed before the storage of gastroscopes and colonoscopes, water droplets were observed eight times (35\%) during 23 gastrointestinal endoscope 
TABLE 1: Characteristics of the quasi-randomized controlled trials.

\begin{tabular}{|c|c|c|c|c|c|c|}
\hline $\begin{array}{l}\text { First } \\
\text { author } \\
\text { (year) }\end{array}$ & Country & Study design & Intervention methods & Sample & $\begin{array}{c}\text { Outcomes and } \\
\text { measurement }\end{array}$ & Conclusions \\
\hline $\begin{array}{l}\text { Kovaleva } \\
(2010) \\
{[29]}\end{array}$ & Netherlands & $\begin{array}{l}\text { Quasirandomized } \\
\text { controlled trial }\end{array}$ & $\begin{array}{l}\text { (a) PAA-based } \\
\text { disinfectant with } \\
\text { additional sterile } \\
\text { compressed air(SCA) } \\
\text { (b) PAA-based } \\
\text { disinfectant without } \\
\text { additional drying }\end{array}$ & $\begin{array}{l}\text { Biofilm in } \\
\text { endoscopes }\end{array}$ & $\begin{array}{l}\text { MTT signal, colony- } \\
\text { forming units }\end{array}$ & $\begin{array}{l}\text { PAA-based disinfectant with } \\
\text { SCA reliably removed biofilm } \\
\text { additional }\end{array}$ \\
\hline $\begin{array}{l}\text { Grandval } \\
(2013) \\
{[24]}\end{array}$ & France & $\begin{array}{l}\text { Quasirandomized } \\
\text { controlled trial }\end{array}$ & $\begin{array}{l}\text { (a) Storage cabinets for } \\
\text { heat-sensitive } \\
\text { endoscopes (SCHE) } \\
\text { (b) Clean, dry, } \\
\text { dedicated cupboard } \\
\text { without morning } \\
\text { disinfection } \\
\text { (c) Clean, dry, } \\
\text { dedicated cupboard } \\
\text { with morning } \\
\text { disinfection }\end{array}$ & $\begin{array}{l}\text { Endoscopes } \\
(n=41)\end{array}$ & $\begin{array}{c}\text { Endoscope } \\
\text { contamination levels }\end{array}$ & $\begin{array}{l}\text { SCHE might maintain the } \\
\text { microbiological quality of } \\
\text { endoscopes }\end{array}$ \\
\hline $\begin{array}{l}\text { Saliou } \\
(2015) \\
{[25]}\end{array}$ & France & $\begin{array}{l}\text { Quasirandomized } \\
\text { controlled trial }\end{array}$ & $\begin{array}{l}\text { (a) In a clean, dry, } \\
\text { dedicated cupboard } \\
\text { (b) In an AS300 Hysis } \\
\text { SCHE }\end{array}$ & $\begin{array}{l}\text { (a) } n=60 \\
\text { (b) } n=69\end{array}$ & $\begin{array}{c}\text { Endoscope } \\
\text { contamination levels }\end{array}$ & $\begin{array}{l}\text { The use of SCHE significantly } \\
\text { reduced the rate of } \\
\text { contaminated endoscopes }\end{array}$ \\
\hline $\begin{array}{l}\text { Hassaine- } \\
\text { Lahfa } \\
(2017) \\
{[27]}\end{array}$ & Algeria & $\begin{array}{l}\text { Quasirandomized } \\
\text { controlled trial }\end{array}$ & $\begin{array}{l}\text { (a) Without drying the } \\
\text { material after } \\
\text { sterilization } \\
\text { (b) Drying the } \\
\text { endoscope's channels } \\
\text { with compressed air } \\
\text { after sterilization }\end{array}$ & $\begin{array}{l}\text { (a) } n=100 \\
\text { (b) } n=200\end{array}$ & $\begin{array}{l}\text { The number of } \\
\text { Candida sp. isolates }\end{array}$ & $\begin{array}{l}\text { The effects of drying by } \\
\text { compressed air enhanced their } \\
\text { sterilization }\end{array}$ \\
\hline $\begin{array}{l}\text { Wong } \\
\text { Chan } \\
(2017) \\
{[26]}\end{array}$ & China & $\begin{array}{l}\text { Quasirandomized } \\
\text { controlled trial }\end{array}$ & $\begin{array}{l}\text { (a) Without drying } \\
\text { (b) Dried with } \\
\text { compressed air } \\
\text { (c) With } 75 \% \text { alcohol } \\
\text { then dried with } \\
\text { compressed air }\end{array}$ & $\begin{array}{l}\text { (a) } n=99 \\
\text { (b) } n=96 \\
\text { (c) } n=105\end{array}$ & $\begin{array}{l}\text { Colony-forming } \\
\text { units; detection rates } \\
\text { of pathogenic } \\
\text { microorganism }\end{array}$ & $\begin{array}{l}75 \% \text { alcohol plus compressed } \\
\text { air enhanced their sterilization } \\
\text { and was superior to } \\
\text { compressed air }\end{array}$ \\
\hline $\begin{array}{l}\text { Barakat } \\
(2019) \\
{[20]}\end{array}$ & America & $\begin{array}{l}\text { Quasirandomized } \\
\text { controlled trial }\end{array}$ & $\begin{array}{l}\text { (a) Manual forced air } \\
\text { drying } \\
\text { (b) Automated drying } \\
\text { for } 5 \text { min } \\
\text { (c)Automated drying } \\
\text { for } 10 \mathrm{~min}\end{array}$ & $\begin{array}{l}\text { Endoscopes } \\
(n=23)\end{array}$ & $\begin{array}{l}\text { Retained fluid; ATP } \\
\text { bioluminescence } \\
\text { values }\end{array}$ & $\begin{array}{l}\text { Automated drying may } \\
\text { decrease the risk of endoscope } \\
\text { infection transmission }\end{array}$ \\
\hline
\end{tabular}

MTT: measuring the tetrazolium salt; PAA: peracetic acid-based; SCHE: storage cabinet for heat-sensitive endoscopes; ATP: adenosine triphosphate bioluminescence. SEM: scanning electron microscopy.

examinations. After at least 2 min of additional compressed air drying before storage, no obvious droplets were found. Three endoscopes were vertically stored in a ventilation cabinet for $30 \mathrm{~h}$, and residual droplets were found. After six days of continuous storage, one gastroscope also had obvious moisture [21]. Similar phenomena were also observed in other trials. After $10 \mathrm{~min}$ of manual compressed air drying, a small amount of residual droplets was observed in $42.6 \%$ (29/68) of endoscope working channels, with a mean \pm SD of $0.62 \pm 0.95$ residual droplets and higher ATP bioluminescence values $(p<0.001)$ [22]. Other researchers [23] investigated 45 reprocessed endoscopes in three American hospitals. After storage for $24 \mathrm{~h}$ to $48 \mathrm{~h}$, evidence showed that residual droplets were observed in 21 of 45 (47\%) endoscope channels; moisture was detected in 22 (49\%) endoscopes; and 10 (22\%) endoscope ATP levels were up to 200 RLU. Residual droplets were strongly associated with the level of maximum ATP $(p<0.01)$ [23]. Barakat et al. [20] used three drying methods, including $10 \mathrm{~min}$ of manual compressed air drying, $5 \mathrm{~min}$ of automatic drying, and 10 minutes of automatic drying. The experimental results showed that 5 endoscope tips observed immediately after manual compressed air drying for $10 \mathrm{~min}$ had droplet discharge, with a mean \pm SD of $4.55 \pm 6.14$ droplets; however, after 5 min of 
TABLE 2: Characteristics of the prevalence studies.

\begin{tabular}{|c|c|c|c|c|c|c|}
\hline $\begin{array}{l}\text { First } \\
\text { author } \\
\text { (year) }\end{array}$ & Country & $\begin{array}{l}\text { Study } \\
\text { design }\end{array}$ & Survey methods & Sample & Outcomes and measurement & Conclusions \\
\hline $\begin{array}{l}\text { Barbosa } \\
(2020) \\
{[18]}\end{array}$ & Brazil & $\begin{array}{l}\text { Prevalence } \\
\text { study }\end{array}$ & $\begin{array}{c}\text { Data in a checklist were } \\
\text { collected by direct } \\
\text { observation }\end{array}$ & $\begin{array}{l}\text { Endoscopes } \\
\quad(n=60)\end{array}$ & $\begin{array}{l}\text { Endoscope reprocessing } \\
\text { procedures }\end{array}$ & $\begin{array}{l}\text { Failure in many different } \\
\text { reprocessing steps: prewash, } \\
\text { chemical, and mechanical } \\
\text { cleaning, and the rinsing and } \\
\text { drying of the endoscopes }\end{array}$ \\
\hline $\begin{array}{l}\text { Ren-Pei } \\
(2014) \\
{[28]}\end{array}$ & China & $\begin{array}{l}\text { Prevalence } \\
\text { study }\end{array}$ & $\begin{array}{l}\text { The questionnaire was sent to } \\
66 \text { hospitals to investigate } \\
\text { reprocessing procedures for } \\
\text { endoscopes }\end{array}$ & $\begin{array}{l}\text { Endoscopes } \\
\quad(n=66)\end{array}$ & $\begin{array}{l}\text { Endoscope channel tubing } \\
\text { samples were observed by } \\
\text { scanning electron } \\
\text { microscopy (SEM) }\end{array}$ & $\begin{array}{c}\text { The formation of endoscopic } \\
\text { biofilm may be related to } \\
\text { reuse of detergent, manual } \\
\text { cleaning, and incomplete } \\
\text { drying }\end{array}$ \\
\hline $\begin{array}{l}\text { Barakat } \\
(2018) \\
{[22]}\end{array}$ & America & $\begin{array}{l}\text { Prevalence } \\
\text { study }\end{array}$ & $\begin{array}{c}\text { A total of } 85 \text { inspections were } \\
\text { performed on all } 68 \\
\text { endoscopes in our endoscopy } \\
\text { unit }\end{array}$ & $\begin{array}{l}\text { Endoscopes } \\
\quad(n=68)\end{array}$ & $\begin{array}{c}\text { Endoscope working } \\
\text { channels were examined by } \\
\text { the SteriCam }\end{array}$ & $\begin{array}{l}\text { Residual fluid in our study } \\
\text { was most commonly noted } \\
\text { with in the first } 24 \text { hours after } \\
\text { reprocessing, some for up to } \\
72 \text { hours }\end{array}$ \\
\hline $\begin{array}{l}\text { Ofstead } \\
(2018) \\
{[23]}\end{array}$ & America & $\begin{array}{l}\text { Prevalence } \\
\text { study }\end{array}$ & $\begin{array}{l}\text { Researchers conducted field } \\
\text { surveys of fully reprocessed } \\
\text { endoscopes. Data were } \\
\text { collected during site visits }\end{array}$ & $\begin{array}{l}\text { Endoscopes } \\
\quad(n=45)\end{array}$ & $\begin{array}{l}\text { Endoscopes were stored for } \\
24-48 \mathrm{~h} \text { before visual } \\
\text { examinations; retained fluid } \\
\text { was photographed with a } \\
\text { camera and borescopes }\end{array}$ & $\begin{array}{l}\text { Inadequate reprocessing and } \\
\text { drying contributed to } \\
\text { retained fluid and } \\
\text { contamination found in a } \\
\text { multisite study }\end{array}$ \\
\hline $\begin{array}{l}\text { Thaker } \\
\text { (2018) } \\
{[19]}\end{array}$ & America & $\begin{array}{l}\text { Prevalence } \\
\text { study }\end{array}$ & $\begin{array}{l}\text { A pilot inspection study } \\
\text { using a prototype borescope } \\
\text { was performed on routinely } \\
\text { used endoscopes after HLD, } \\
\text { manual forced-air dry of the } \\
\text { instrument channel }\end{array}$ & $\begin{array}{l}\text { Endoscopes } \\
\quad(n=59)\end{array}$ & $\begin{array}{l}\text { Video recordings were } \\
\text { reviewed for visible } \\
\text { moisture, debris, } \\
\text { discoloration, scratches, } \\
\text { channel shredding, and } \\
\text { visible evidence of biofilm }\end{array}$ & $\begin{array}{l}\text { Manual forced-air drying of } \\
\text { the channel appears to be } \\
\text { highly effective in eliminating } \\
\text { moisture compared with } \\
\text { overnight hang drying alone }\end{array}$ \\
\hline $\begin{array}{l}\text { Thaker } \\
(2018) \\
{[21]}\end{array}$ & America & $\begin{array}{l}\text { Prevalence } \\
\text { study }\end{array}$ & $\begin{array}{l}\text { The survey was sent } \\
\text { electronically to providers } \\
\text { who potentially performed or } \\
\text { participated in ERCP in the } \\
\text { United States }\end{array}$ & $\begin{array}{l}\text { Institutions } \\
(n=249)\end{array}$ & $\begin{array}{l}\text { Reprocessing techniques, } \\
\text { barriers to ethylene oxide } \\
\text { sterilization, microbial } \\
\text { testing, reprocessing } \\
\text { opinions }\end{array}$ & $\begin{array}{l}\text { Improved adherence to } \\
\text { forced-air drying in } \\
\text { duodenoscope reprocessing } \\
\text { is needed }\end{array}$ \\
\hline
\end{tabular}

SEM: scanning electron microscopy; HLD: high-level disinfection; ERCP: endoscopic retrograde cholangiopancreatography.

automatic drying, only a few droplets were observed, with a mean \pm SD of $0.83 \pm 1.29$ droplets. After 10 min of automatic drying, the average was 0 droplets, and after $72 \mathrm{~h}$ of storage, none of the three drying methods resulted in droplets. Whether manual compressed air drying for 10 min significantly differed from automatic drying for $5 \mathrm{~min}$ or compared with automatic drying for $10 \mathrm{~min}$, the number of residual droplets was statistically significant, but ATP bioluminescence values were not statistically significant [20].

3.3.3. Microbial Contamination. Four articles mainly explored microbial contamination after gastrointestinal endoscope drying [24-27]. Grandval et al. [24] compared the drying effects of storage cabinets for heat-sensitive endoscopes (SCHE) (all endoscope channels were sequentially rinsed with medical-grade air or highly efficient filtered particulate air (HEPA) to achieve air circulation for $10 \mathrm{~min}$ per endoscope and achieve a drying effect) and the drying effects of a conventional storage cabinet, showing that $56.1 \%(n=23)$ of endoscopes in the intervention group were not contaminated. After identification, the main microorganisms were coagulase-negative staphylococci, Micrococcus, and
Bacillus, and there was no significant difference between the two groups ( $p=0.829)$ [24]. Saliou et al. [25] compared the levels of microbes before and after installation of SCHE. The results showed that $45.0 \%(n=60)$ of endoscope contamination was detected before installation and only $13.0 \%$ $(n=69)$ was detected after installation. There was a significant difference $(p<0.001)$ before and after installation. The identified microbes were mainly Pseudomonas aeruginosa, E. coli, Bacillus maltophilia, pneumococcus, and Staphylococcus aureus, and Candida was also found in a sample [25]. The effects of drying on Candida were evaluated. The results of endoscope sterilization without drying were compared with that of first sterilizing and then drying endoscope channels with compressed air. Evidence demonstrated that 25 Candida strains were isolated at the first evaluation and 9 Candida strains were isolated in the final two evaluations [27]. Chan et al. [26] used $30 \mathrm{ml}$ of $75 \%$ ethanol to rinse each channel of the endoscope, let the channels sit for $3 \mathrm{~min}$, and then flushed each channel with compressed air for $30 \mathrm{~s}$; the qualified rate of microbial detection from this method was compared with the qualified rate of microbial detection without drying and compressed air flushing for $30 \mathrm{~s}$. There was a 
TABLE 3: Characteristics of the interventions.

\begin{tabular}{|c|c|c|c|c|c|c|c|c|c|}
\hline $\begin{array}{l}\text { First } \\
\text { author }\end{array}$ & Year & Intervention description & \multicolumn{7}{|c|}{ Duration } \\
\hline Kovaleva & $(2010)$ & $\begin{array}{l}\text { (a) PAA-based disinfectant with addition } \\
\text { sterile compressed air (SCA) } \\
\text { (b) PAA-based disinfectant without additional } \\
\text { sterile compressed air }\end{array}$ & \multicolumn{7}{|c|}{$\begin{array}{l}\text { (a) Using SCA for } 2 \mathrm{~h} \text { at } 50^{\circ} \mathrm{C} \text {. The two interventions were stored in } \\
\text { al drying cabinets for } 1,3,5 \text {, and } 7 \text { days }\end{array}$} \\
\hline Grandval & $(2013)$ & $\begin{array}{l}\text { (a) AEWD then storage cabinets for heat- } \\
\text { sensitive endoscopes (SCHE) } \\
\text { (b) AEWD then in a clean, dry, dedicated } \\
\text { cupboard without morning disinfection } \\
\text { (c) AEWD then in a clean, dry, dedicated } \\
\text { cupboard with morning disinfection }\end{array}$ & \multicolumn{7}{|c|}{ Endoscopes of the three interventions were stored for $72 \mathrm{~h}$ then sampled } \\
\hline Saliou & $(2015)$ & $\begin{array}{l}\text { (a) AEWD then in a clean, dry, dedicated } \\
\text { cupboard } \\
\text { (b) AEWD then in an AS300 Hysis SCHE }\end{array}$ & \multicolumn{7}{|c|}{$\begin{array}{l}\text { (a) High-level disinfection after } 12 \mathrm{~h} \text { of storage as recommended in } \\
\text { France } \\
\text { (b) All channels of the endoscopes were purged with medical air for } 1 \\
\text { hour }\end{array}$} \\
\hline $\begin{array}{l}\text { Hassaine- } \\
\text { Lahfa }\end{array}$ & $(2017)$ & $\begin{array}{l}\text { (a) Without drying the material after } \\
\text { sterilization } \\
\text { (b) Drying the endoscope's channels with } \\
\text { compressed air after sterilization }\end{array}$ & \multicolumn{7}{|c|}{$\begin{array}{l}\text { Endoscopes of the two interventions were immersed in Hexanios for } 20 \\
\text { minutes and Steranios } 2 \% \text { for } 15 \text { minutes }\end{array}$} \\
\hline $\begin{array}{l}\text { Wong } \\
\text { Chan }\end{array}$ & $(2017)$ & $\begin{array}{l}\text { (a) Without drying } \\
\text { (b) Dried with compressed air } \\
\text { (c) With } 75 \% \text { alcohol then dried with } \\
\text { compressed air }\end{array}$ & \multicolumn{7}{|c|}{$\begin{array}{l}\text { (a) Dried with compressed air for } 30 \mathrm{~s} \\
\text { (b) With } 75 \% \text { alcohol for } 3 \text { min then dried with compressed air for } 30 \mathrm{~s}\end{array}$} \\
\hline Barakat & $(2019)$ & $\begin{array}{l}\text { (a) AER plus manual forced air drying } \\
\text { (b) AER plus automated drying for } 5 \mathrm{~min} \\
\text { (c) AER plus automated drying for } 10 \mathrm{~min}\end{array}$ & \multicolumn{7}{|c|}{$\begin{array}{l}\text { (a) Manual drying of the endoscope working channel for } 10 \text { minutes } \\
\text { with forced high-efficiency particulate filtered air (HEPA) } \\
\text { (b) and (c) Endoscopes were attached to the Dri-Scope Aid device for } \\
\text { either } 5 \text { minutes or } 10 \text { minutes }\end{array}$} \\
\hline \multicolumn{10}{|c|}{$\begin{array}{l}\text { PAA: peracetic acid-based; SCA: sterile compressed air; AEWD: automatic endoscope washer-disinfector; SCHE: storage cabinets for heat-sensitive endoscopes } \\
\text { AER: automated endoscope reprocessor; HEPA: high-efficiency particulate air. }\end{array}$} \\
\hline $\begin{array}{l}\text { First } \\
\text { author }\end{array}$ & & Drying methods & $\begin{array}{l}\text { doscopy of } \\
\text { oplets }(n)\end{array}$ & $\begin{array}{l}\text { Total } \\
\text { endoscopy } \\
\quad\left(n_{1}\right)\end{array}$ & $\begin{array}{l}n / n_{1} \\
(\%)\end{array}$ & $\begin{array}{l}\leq 30 \min \\
\text { droplets }\end{array}$ & $\begin{array}{c}24 \mathrm{~h} \\
\text { droplets }\end{array}$ & $\begin{array}{l}48 \mathrm{~h} \\
\text { droplets }\end{array}$ & $\begin{array}{l}\geq 72 \mathrm{~h} \\
\text { droplets }\end{array}$ \\
\hline Barakat & $\begin{array}{r}\text { AER (alc } \\
\mathrm{m}\end{array}$ & $\begin{array}{l}\text { cohol flushing and } 1 \mathrm{~min} \text { air flushing) and } \\
\text { tanual forced air drying for } 10 \mathrm{~min}\end{array}$ & 5 & 5 & 100 & $\begin{array}{c}4.55 \\
(6.14)\end{array}$ & $\begin{array}{c}1.62 \\
(1.61)\end{array}$ & $\begin{array}{l}0.51 \\
(0.7)\end{array}$ & $0(0)$ \\
\hline Barakat & AER (alc & $\begin{array}{l}\text { cohol flushing and } 1 \text { min air flushing) and } \\
\text { automated drying for } 5 \mathrm{~min}\end{array}$ & 4 & 5 & 80 & $\begin{array}{c}0.83 \\
(1.29)\end{array}$ & $\begin{array}{c}0.20 \\
(0.34)\end{array}$ & $\begin{array}{c}0.04 \\
(0.11)\end{array}$ & $0(0)$ \\
\hline Barakat & AER (alc & $\begin{array}{l}\text { cohol flushing and } 1 \mathrm{~min} \text { air flushing) and } \\
\text { automated drying for } 10 \mathrm{~min}\end{array}$ & 0 & 5 & 0 & $0(0)$ & $\begin{array}{c}0.01 \\
(0.07)\end{array}$ & $0(0)$ & $0(0)$ \\
\hline Ofstead & $\begin{array}{l}\text { AER (alc } \\
\text { medi }\end{array}$ & $\begin{array}{l}\text { cohol flushing and } 1 \mathrm{~min} \text { air flushing) and } \\
\text { ical-grade forced air drying for } 10 \mathrm{~min}\end{array}$ & 21 & 45 & 47 & Not done & a few & a few & $\begin{array}{l}\text { Not } \\
\text { done }\end{array}$ \\
\hline Barakat & $\begin{array}{r}\text { AER (alc } \\
\mathrm{m}\end{array}$ & $\begin{array}{l}\text { cohol flushing and } 1 \mathrm{~min} \text { air flushing) and } \\
\text { tanual forced air drying for } 10 \mathrm{~min}\end{array}$ & 29 & 68 & 42.60 & $\begin{array}{c}0.62 \\
(0.95)\end{array}$ & $\begin{array}{l}\text { Not } \\
\text { done }\end{array}$ & $\begin{array}{l}\text { Not } \\
\text { done }\end{array}$ & $\begin{array}{l}\text { Not } \\
\text { done }\end{array}$ \\
\hline Thaker & $\begin{array}{r}\text { Manual } \\
\text { Medic }\end{array}$ & $\begin{array}{l}1 \text { forced-air drying at room temperature. } \\
\text { al air for more than } 2 \mathrm{~min} \text { in each port }\end{array}$ & 8 & 97 & 8.2 & Not done & A few & $\begin{array}{l}\text { Not } \\
\text { done }\end{array}$ & Rare \\
\hline
\end{tabular}

AER: automated endoscope reprocessor.

significant difference (A group, 73.73\%; B group, 77.08\%; C group, $89.52 \%)$. Gram-positive bacteria were the most common (mainly Micrococcus and Bacillus subtilis).

3.3.4. Biofilm Formation. Two articles described the formation of biofilms found in working channels after endoscope drying [28, 29]. Researchers [28] sent questionnaires in envelopes by mail to endoscopy centre in 66 hospitals across the country. Endoscopic channel tubing samples from 66 hospitals were observed by scanning electron microscopy (SEM), and the corresponding endoscope reprocessing procedures were investigated in 66 hospitals. Significant biofilm growth 
was observed in $36(36 / 66,54.6 \%)$ hospitals with 36 endoscope aspiration and biopsy channels and 10 (10/13, 76.9\%) water and gas delivery channels. The ratio of alcohol use and air drying in these hospitals was $38.9 \%$ (14/36). No biofilms were observed in $76.7 \%(23 / 30)$ of hospitals $(p=0.002)$ [28]. Kovaleva et al. [29] established an endoscope biofilm model in vitro. First, common Candida strains were isolated from endoscopes. One of the colonies was inoculated in trypsin soybean broth and incubated at $37^{\circ} \mathrm{C}$ for $18 \mathrm{~h}$ to simulate the formation of endoscope channel biofilms. Disinfection was performed using 1\% PAA base disinfectant and then dried using compressed air at $50^{\circ} \mathrm{C}$ for $2 \mathrm{~h}$ to simulate the disinfection and drying process of endoscope reprocessing, and the endoscope was finally stored in a drying cabinet for 7 days. The results showed that the biofilm regenerated after disinfectant treatment without drying, but after drying at $50^{\circ} \mathrm{C}$ for $2 \mathrm{~h}$ or at room temperature for 1,3 , or 5 days, there was no biofilm regeneration [29].

\section{Discussion}

To the best of our knowledge, this is the first systematic review that summarizes the current status of gastrointestinal endoscope drying methods and assesses their effectiveness in preventing residual droplets, microorganisms, and biofilms. This review included a total of 12 articles, with approximately 345 institutions and 783 endoscopes in 958 examinations, which allowed important conclusions on potential advantages and limitations during gastrointestinal endoscope drying. This review showed that the extent of endoscopic drying was not sufficient in clinical practice, as recommended in existing guidelines for gastrointestinal endoscope reprocessing; moreover, the guidelines or statements for endoscope reprocessing around the world are inconsistent, and no clear and uniform requirements have been made on the duration and method of drying. Gastrointestinal endoscopes still had residual droplets, microbial growth, and biofilm formation after reprocessing and drying, but we found that automatic endoscope reprocessor (AER) plus Dri-Scope Aid automatic drying was obviously better than AER plus manual drying and the use of drying cabinet once again reduced the residue of droplets and the growth of microorganisms, thus improving the quality of gastrointestinal endoscope reprocessing.

Drying procedure is an important factor affecting the quality of gastrointestinal endoscope reprocessing and should not be underestimated [30, 31], and the drying method is a vital means to improve the drying effect [32]. Insufficient endoscope drying allows microbes to easily breed, causing infections in patients. Five studies in France reported the isolation of Bacillus pneumoniae and multidrug-resistant Pseudomonas aeruginosa from duodenoscopes and gastroscopes used in patients. An examination of the endoscope reprocessing procedures revealed that the cleaning and drying times were too short to adequately comply with endoscope reprocessing guidelines [30, 33-36]. In order to standardize the procedure of gastrointestinal endoscope reprocessing, some national gastrointestinal endoscopy societies have developed guidelines for gastrointestinal endoscope reprocessing. Although each procedure of the guidelines for endoscopic reprocessing varies slightly between countries, there is not much difference overall. Because of the lack of strict regulation and supervision of the best methods for drying of endoscopes after HLD, it is not novel that the actual drying practices vary greatly between institutions, even if the same medical system is used $[19,22,23]$. In summary, endoscope drying can be performed with an automatic endoscope reprocessor, which involves cleaning, a high level of disinfection, and one minute of air flushing; rinsing first with $70 \%$ to $90 \%$ ethyl or isopropyl alcohol and then manual drying using a safety air gun with compressed air for $30 \mathrm{~s}$ or $10 \mathrm{~min}$; and AER plus DriScope Aid for automatic drying for $5 \mathrm{~min}$ or $10 \mathrm{~min}$ or in a drying/traditional storage cabinet [20, 24-26].

According to the Australian Infection Control in Endoscopy Consensus Statements [37], Korean Society of Gastrointestinal Endoscopy Guidelines [38], Multisociety guideline on reprocessing flexible GI endoscopes [39], American Society for Gastrointestinal Endoscopy (ASGE) [40], Association for Professionals in Infection Control (APIC) [41], Japan Gastroenterological Endoscopy Society (JGEC) [42], World Gastroenterology Organization/World Endoscopy Organization (WGO/WEO) Global Guidelines $[43,44]$, Canada Infection Prevention and Control Guideline [45], and Society of Gastroenterology Nurses and Associates [46], $70 \%$ to $90 \%$ alcohol should be used to flush the endoscope working channel before storage, followed by thorough compressed air drying (AER or AER plus manual drying). Alcohol flushing can not only accelerate the drying process but also inhibit the possible existence of water microorganisms. However, the British Society of Gastroenterology Endoscopy Guidelines (BSGES) for decontamination of equipment for gastrointestinal endoscopy $[47,48]$ and European Society of Gastrointestinal Endoscopy (ESGE) guideline [11] highlight that its use is not recommended because alcohol has potentially fixed effects and unknown risks. Some studies $[26,49]$ revealed that alcohol flushing can effectively reduce the chance of residual droplets and microbial growth in endoscope channels. Our comprehensive analysis also showed that alcohol facilitated drying of endoscope channels and its use was not found to endanger the health of others.

Our results indicated that AER plus Dri-Scope Aid for automatic drying for $5 \mathrm{~min}$ or $10 \mathrm{~min}$ was significantly better than AER or AER plus manual drying in preventing residual droplets and microbial growth. While the Dri-Scope Aid for automatic drying was not mentioned in the gastrointestinal endoscopy guidelines, a recent trial suggested that the DriScope Aid for automatic drying for $10 \mathrm{~min}$ seemed to greatly reduce the risk of microbial contamination and droplet residue [20]. The Dri-Scope Aid device provides an automatic method to manage forced air in programming time and completes the drying of all endoscope channels, which effectively avoids the mistakes caused by manual drying [20]. The Centers for Disease Control [50] also placed special emphasis on automation of reprocessing to "reduce the likelihood that the necessary reprocessing steps will be skipped." However, the evidence strongly supporting similar conclusions about endoscopic drying is rather limited, with only one trial [20]. 
Whether AER plus Dri-Scope Aid for automatic drying can efficaciously prevent droplet residue and microbial growth needs to be further verified by more high-quality clinical trials.

In addition, our review also showed that the use of drying cabinets can reduce the risk of microbial contamination. As guided by many guidelines [47, 48, 51, 52], endoscopes should be stored in a drying cabinet with a drying system that circulates and forces sterile, dry, and filtered air through the endoscope channels. Compressed filtered air can minimize the risk of microbial contamination of cabinets and stored endoscopy. The guidelines do not specify how long endoscopes are stored in the drying cabinet to achieve adequate drying. Several experiments $[24,25,53]$ revealed that endoscopes were dried and stored in a drying cabinet for 72 hours, making the results of endoscope microbial quality satisfactory.

As no single drying method has been shown to be valid to achieve endoscope channels without droplet residue and microbial growth, one may speculate that multiple times, combined drying methods based on a case-by-case decision may have the potential to affect the final endoscope reprocessing quality. In fact, this is the key information of a recent trial, where implementation of the process of twice endoscopic reprocessing resulted in significant improvements about the residue in the endoscope [54]. In clinical practice, it is best to recommend using the Dri-Scope Aid to dry for more than 10 minutes or to store in the drying cabinet for 24 hours, and if necessary, to carry out two cycles of reprocessing, which can minimize fluid residues and microbial contamination in endoscope channels and avoid crossinfection between patients, thus providing some reference significance for the later updating of the guidelines for gastrointestinal endoscopy reprocessing. In the future, we will further research a combined drying method, including the use of an automatic endoscope reprocessing machine for initial drying, followed by the use of Dri-Scope Aid for final drying and eventually stored in a drying cabinet to explore the optimal drying method and drying time.

\section{Limitations}

There were several potential limitations in this systematic review. We included quasirandomized controlled trials and prevalence studies. The selection criteria and grouping processes for samples from these studies differed. Moreover, the heterogeneity was large mainly because there were different drying methods, including manual drying, automatic drying, and drying cabinets. The effectiveness of automatic drying was well demonstrated. Most studies did not adequately report the process of gastrointestinal endoscopic drying, limiting further analysis of the details of the drying procedure.

\section{Conclusions}

Accurate drying and storage procedures are important for maintaining bacteria-free endoscopes. Many national guidelines have repeatedly emphasized that effective drying of the internal and external surfaces of endoscopes was as important as effective cleaning, disinfection, or sterilization and that endoscopic equipment must be thoroughly dried before storage to prevent microbial reproduction $[1,11,38,51,55$, 56]. However, there are few prevalence studies and quasirandomized controlled trials on the current status of gastrointestinal endoscope drying. Therefore, whether existing drying methods can thoroughly dry endoscope working channels requires further verification. This systematic review reports that endoscope drying practices may not always effectively remove residual droplets, microorganisms, and biofilms in endoscopes, but existing evidence suggests that automatic drying may be superior to other drying methods, drying for more than $10 \mathrm{~min}$ or storing in drying cabinets for more than $72 \mathrm{~h}$, which highlights the importance of strict adherence to drying guidelines to make drying procedures more standardized and automated. In addition, the implementation of multicentre, large-sample, and high-quality studies to compare the effectiveness of different drying methods for droplets, microorganisms, and biofilms in endoscope working channels is necessary.

\section{Conflicts of Interest}

The authors declare that they have no conflict of interests.

\section{Authors' Contributions}

Hefeng Tian reviewed the design and performed statistical analysis, data interpretation, and manuscript writing. Jiao Sun reviewed the design, reviewed the design supervision, and performed data interpretation and manuscript revision. Shaoning Guo reviewed the design and performed manuscript revision. Xuanrui Zhu, Han Feng, and Yijing Zhuang performed data collection and analysis and interpretation. Xiu Wang reviewed the concept, reviewed the design, and performed data interpretation and manuscript revision. Hefeng Tian, Jiao Sun, and Shaoning Guo are considered as first authors.

\section{Supplementary Materials}

Supplementary file 1: search strategy. (Supplementary Materials)

\section{References}

[1] B. T. Petersen, J. Chennat, J. Cohen et al., "Multisociety guideline on reprocessing flexible gastrointestinal endoscopes: 2011," Gastrointestinal Endoscopy, vol. 73, no. 6, pp. 1075$1084,2011$.

[2] H. Li, X. Hou, R. Lin et al., "Advanced endoscopic methods in gastrointestinal diseases: a systematic review," Quantitative Imaging in Medicine and Surgery, vol. 9, no. 5, pp. 905-920, 2019.

[3] N. Kenters, E. Huijskens, C. Meier, and A. Voss, "Infectious diseases linked to cross-contamination of flexible endoscopes," Endoscopy International Open, vol. 3, no. 4, pp. E259-E265, 2015. 
[4] N. Kenters, E. Tartari, J. Hopman et al., "Worldwide practices on flexible endoscope reprocessing," Antimicrobial Resistance and Infection Control, vol. 7, no. 1, p. 153, 2018.

[5] C. L. Ofstead, A. M. Dirlam Langlay, N. J. Mueller, P. K. Tosh, and H. P. Wetzler, "Re-evaluating endoscopy-associated infection risk estimates and their implications," American Journal of Infection Control, vol. 41, no. 8, pp. 734-736, 2013.

[6] L. Epstein, J. C. Hunter, M. A. Arwady et al., "New Delhi metallo- $\beta$-lactamase-producing carbapenem-resistant Escherichia coli associated with exposure to duodenoscopes," JAMA, vol. 312, no. 14, pp. 1447-1455, 2014.

[7] P. Gastmeier and R. P. Vonberg, "Klebsiella spp. in endoscopyassociated infections: we may only be seeing the tip of the iceberg," Infection, vol. 42, no. 1, pp. 15-21, 2014.

[8] S. B. Jørgensen, M. S. Bojer, E. J. Boll et al., "Heat-resistant, extended-spectrum $\beta$-lactamase-producing Klebsiella pneumoniae in endoscope-mediated outbreak," The Journal of Hospital Infection, vol. 93, no. 1, pp. 57-62, 2016.

[9] W. A. Rutala and D. J. Weber, "Outbreaks of carbapenemresistant Enterobacteriaceae infections associated with duodenoscopes: what can we do to prevent infections?," American Journal of Infection Control, vol. 44, no. 5, pp. e47-e51, 2016.

[10] C. G. Roberts, "The role of biofilms in reprocessing medical devices," American Journal of Infection Control, vol. 41, no. 5, pp. S77-S80, 2013.

[11] U. Beilenhoff, H. Biering, R. Blum et al., "Reprocessing of flexible endoscopes and endoscopic accessories used in gastrointestinal endoscopy: position statement of the European Society of Gastrointestinal Endoscopy (ESGE) and European Society of Gastroenterology Nurses and Associates (ESGENA) - update 2018," Endoscopy, vol. 50, no. 12, pp. 1205-1234, 2018.

[12] R. L. Bartles, J. E. Leggett, S. Hove et al., “A randomized trial of single versus double high-level disinfection of duodenoscopes and linear echoendoscopes using standard automated reprocessing," Gastrointestinal Endoscopy, vol. 88, no. 2, pp. 306313.e302, 2018.

[13] S. Bhatt, P. Mehta, C. Chen et al., "Efficacy of low-temperature plasma-activated gas disinfection against biofilm on contaminated GI endoscope channels," Gastrointestinal Endoscopy, vol. 89, no. 1, pp. 105-114, 2019.

[14] H. Singh, D. R. Duerksen, G. Schultz et al., "Impact of cleaning monitoring combined with channel purge storage on elimination of Escherichia coli and environmental bacteria from duodenoscopes," Gastrointestinal Endoscopy, vol. 88, no. 2, pp. 292-302, 2018.

[15] G. M. Snyder, S. B. Wright, A. Smithey et al., "Randomized comparison of 3 high-level disinfection and sterilization procedures for duodenoscopes," Gastroenterology, vol. 153, no. 4, pp. 1018-1025, 2017.

[16] D. Moher, A. Liberati, J. Tetzlaff, D. G. Altman, and The PRISMA Group, "Preferred reporting items for systematic reviews and meta-analyses: the PRISMA statement," PLoS Medicine, vol. 6, no. 7, article e1000097, 2009.

[17] E. Aromataris and Z. Munn, "Joanna briggs institute reviewer's manual. The joanna briggs (Vol.299)," August 2018, https://reviewersmanual.joannabriggs.org/.

[18] J. M. Barbosa, A. C. S. Souza, A. F. V. Tipple, F. C. Pimenta, L. S. N. de Oliveira Leão, and S. R. M. C. Silva, "Endoscope reprocessing using glutaraldehyde in endoscopy services of Goiânia, Brazil," Arquivos de Gastroenterologia, vol. 47, no. 3, pp. 219-224, 2010.
[19] A. M. Thaker, V. R. Muthusamy, A. Sedarat et al., "Duodenoscope reprocessing practice patterns in U.S. endoscopy centers: a survey study," Gastrointestinal Endoscopy, vol. 88, no. 2, pp. 316-322.e312, 2018.

[20] M. T. Barakat, R. J. Huang, and S. Banerjee, "Comparison of automated and manual drying in the elimination of residual endoscope working channel fluid after reprocessing (with video)," Gastrointestinal Endoscopy, vol. 89, no. 1, pp. 124-132.e122, 2019.

[21] A. M. Thaker, S. Kim, A. Sedarat, R. R. Watson, and V. R. Muthusamy, "Inspection of endoscope instrument channels after reprocessing using a prototype borescope," Gastrointestinal Endoscopy, vol. 88, no. 4, pp. 612-619, 2018.

[22] M. T. Barakat, M. Girotra, R. J. Huang, and S. Banerjee, "Scoping the scope: endoscopic evaluation of endoscope working channels with a new high-resolution inspection endoscope (with video)," Gastrointestinal Endoscopy, vol. 88, no. 4, pp. 601-611.e601, 2018.

[23] C. L. Ofstead, O. L. Heymann, M. R. Quick, J. E. Eiland, and H. P. Wetzler, "Residual moisture and waterborne pathogens inside flexible endoscopes: evidence from a multisite study of endoscope drying effectiveness," American Journal of Infection Control, vol. 46, no. 6, pp. 689-696, 2018.

[24] P. Grandval, G. Hautefeuille, B. Marchetti, L. Pineau, and R. Laugier, "Evaluation of a storage cabinet for heat-sensitive endoscopes in a clinical setting," The Journal of Hospital Infection, vol. 84, no. 1, pp. 71-76, 2013.

[25] P. Saliou, F. Cholet, J. Jézéquel, M. Robaszkiewicz, H. Le Bars, and R. Baron, "The use of channel-purge storage for gastrointestinal endoscopes reduces microbial contamination," Infection Control and Hospital Epidemiology, vol. 36, no. 9, pp. 1100-1102, 2015.

[26] H. Chan, L. Binbin, P. Qiu, A. Fang, and Y. Sihui, "Effect of different drying methods on re-treatment of digestive endoscope," Chinese Journal of Hospital Infection, vol. 27, no. 20, pp. 4787-4790, 2017.

[27] I. Hassaine-Lahfa, Z. Boucherit-Otmani, L. Sari-Belkherroubi, and K. Boucherit, "Retrospective study of Candida sp. contaminations of endoscopes at the University Hospital of Tlemcen (Algeria)," Journal de Mycologie Médicale, vol. 27, no. 2, pp. 127-132, 2017.

[28] W. Ren-Pei, X. Hui-Jun, Q. Ke, W. Dong, N. Xing, and L. Zhao-Shen, "Correlation between the growth of bacterial biofilm in flexible endoscopes and endoscope reprocessing methods," American Journal of Infection Control, vol. 42, no. 11, pp. 1203-1206, 2014.

[29] J. Kovaleva, J. E. Degener, and H. C. van der Mei, "Mimicking disinfection and drying of biofilms in contaminated endoscopes," Journal of Hospital Infection, vol. 76, no. 4, pp. 345$350,2010$.

[30] C. Aumeran, L. Poincloux, B. Souweine et al., "Multidrugresistant Klebsiella pneumoniae outbreak after endoscopic retrograde cholangiopancreatography," Endoscopy, vol. 42, no. 11, pp. 895-899, 2010.

[31] J. Kovaleva, "Endoscope drying and its pitfalls," The Journal of Hospital Infection, vol. 97, no. 4, pp. 319-328, 2017.

[32] A. Murdani, A. Kumar, H. M. Chiu et al., "WEO position statement on hygiene in digestive endoscopy: focus on endoscopy units in Asia and the Middle East," Digestive Endoscopy, vol. 29, no. 1, pp. 3-15, 2017.

[33] A. Carbonne, J. M. Thiolet, S. Fournier et al., "Control of a multihospital outbreak of KPC-producing Klebsiella pneumoniae 
type 2 in France, September to October 2009," Eurosurveillance, vol. 15 , no. $48,2010$.

[34] N. Kassis-Chikhani, D. Decre, P. Ichai et al., "Outbreak of Klebsiella pneumoniae producing KPC-2 and SHV-12 in a French hospital," The Journal of Antimicrobial Chemotherapy, vol. 65 , no. 7 , pp. 1539-1540, 2010.

[35] T. Naas, G. Cuzon, A. Babics et al., "Endoscopy-associated transmission of carbapenem-resistant Klebsiella pneumoniae producing KPC-2 beta-lactamase," The Journal of Antimicrobial Chemotherapy, vol. 65, no. 6, pp. 1305-1306, 2010.

[36] O. Bajolet, D. Ciocan, C. Vallet et al., "Gastroscopy-associated transmission of extended-spectrum beta-lactamase-producing Pseudomonas aeruginosa," The Journal of Hospital Infection, vol. 83, no. 4, pp. 341-343, 2013.

[37] B. M. Devereaux, E. Athan, R. R. Brown et al., "Australian infection control in endoscopy consensus statements on carbapenemase-producing Enterobacteriaceae," Journal of Gastroenterology and Hepatology, vol. 34, no. 4, pp. 650-658, 2019.

[38] B. K. Son, B. W. Kim, W. H. Kim et al., "Korean Society of Gastrointestinal Endoscopy Guidelines for endoscope reprocessing," Clinical Endoscopy, vol. 50, no. 2, pp. 143-147, 2017.

[39] B. T. Petersen, J. Cohen, R. D. Hambrick et al., "Multisociety guideline on reprocessing flexible GI endoscopes: 2016 update," Gastrointestinal Endoscopy, vol. 85, no. 2, pp. 282294.e1, 2017.

[40] S. Banerjee, B. Shen, D. B. Nelson et al., "Infection control during GI endoscopy," Gastrointestinal Endoscopy, vol. 67, no. 6, pp. 781-790, 2008.

[41] M. A. Martin and M. Reichelderfer, "APIC guideline for infection prevention and control in flexible endoscopy," American Journal of Infection Control, vol. 22, no. 1, pp. 19-38, 1994.

[42] R. Iwakiri, K. Tanaka, T. Gotoda et al., "Guidelines for standardizing cleansing and disinfection of gastrointestinal endoscopes," Digestive Endoscopy, vol. 31, no. 5, pp. 477-497, 2019.

[43] "Endoscope disinfection-a resource-sensitive approach," 2016, https://www.worldendo.org/wp-content/uploads/2016/03/ wgo_weo_endoscope_disinfection.pdf.

[44] "Endoscope disinfection update: a guide to resource-sensitive reprocessing," 2019, https://www.worldgastroenterology.org/ UserFiles/file/guidelines/endoscope-disinfection-english-2019 .pdf.

[45] "Infection prevention and control guideline for flexible gastrointestinal endoscopy and flexible bronchoscopy," 2010, https:// www.phac-aspc.gc.ca/nois-sinp/guide/endo/pdf/endo-eng .pdf.

[46] Society of Gastroenterology Nurses and Associates, "Standards of infection control in reprocessing of flexible gastrointestinal endoscopes," Gastroenterology Nursing, vol. 36, no. 4, pp. 293-303, 2013.

[47] "British Society of Gastroenterology. BSG guidelines for decontamination of equipment for gastrointestinal endoscopy," June 2014, http://www.bsg.org.uk/images/stories/ docs/clinical/guidelines/endoscopy/decontamination_2014_ v2.pdf;.

[48] "British Society of Gastroenterology. Potential transmission of multi-resistant bacteria and duodenoscopes," October 2015, http://www.bsg.org.uk/images/stories/docs/clinical/ guidelines/endoscopy/potential_transmission_of_multi_ resistant_bacteria_and_duodenoscopes_15.pdf;2015.
[49] L. Gavaldà, A. R. Olmo, R. Hernández et al., "Microbiological monitoring of flexible bronchoscopes after high-level disinfection and flushing channels with alcohol: results and costs," Respiratory Medicine, vol. 109, no. 8, pp. 1079-1085, 2015.

[50] W. A. Rutala and D. J. Weber, "Healthcare Infection Control Practices Advisory Committee. Guidelines for disinfection and sterilization in healthcare facilities," 2008, https://www .cdc.gov/infectioncontrol/pdf/guidelines/disinfectionguidelines.

[51] M. A. Bashaw, "Guideline implementation: processing flexible endoscopes," AORN Journal, vol. 104, no. 3, pp. 225-236, 2016.

[52] Steering Group for Flexible Endoscope Cleaning and Disinfection (SFERD), "Professional Standard Handbook Flexible Endoscope Cleaning and Disinfection," September 2014, http://wfhss.com/wp-content/uploads/SFERD-ProfessionalStandard-Handbook-3-1-UK-definitief.pdf;2014.

[53] R. B. Perumpail, N. B. Marya, B. L. McGinty, and V. R. Muthusamy, "Endoscope reprocessing: comparison of drying effectiveness and microbial levels with an automated drying and storage cabinet with forced filtered air and a standard storage cabinet," American Journal of Infection Control, vol. 47, no. 9, pp. 1083-1089, 2019.

[54] M. T. Barakat, R. J. Huang, and S. Banerjee, "Simethicone is retained in endoscopes despite reprocessing: impact of its use on working channel fluid retention and adenosine triphosphate bioluminescence values (with video)," Gastrointestinal Endoscopy, vol. 89, no. 1, pp. 115-123, 2019.

[55] A. H. Calderwood, L. W. Day, V. R. Muthusamy et al., "ASGE guideline for infection control during GI endoscopy," Gastrointestinal Endoscopy, vol. 87, no. 5, pp. 1167-1179, 2018.

[56] L. Kelsey, L. Herron-Rice, P. Anderson et al., "Standards of infection control in reprocessing of flexible gastrointestinal endoscopes," Gastroenterology Nursing, vol. 33, no. 1, pp. 7080, 2010. 